\title{
Location determinants of agricultural land prices
}

\author{
Pia Nilsson • Sara Johansson
}

Published online: 8 January 2013

(C) The Author(s) 2013. This article is published with open access at Springerlink.com

\begin{abstract}
This paper analyses determinants of agricultural land prices in Sweden with a particular focus on location-specific factors. An asset-pricing model is used to decompose agricultural land prices into expected returns from land in its current agricultural use and expected returns from its potential use. The model is estimated in a cross regional context where explanatory factors relate to regional variations in land productivity, agricultural support payments and urbanising influences. Results indicate that both agricultural and non-agricultural factors are influential determinants to the price of agricultural land. Estimating marginal effects across the distribution of the dependent variable, non-agricultural factors are shown to be more important in regions that have high agricultural land prices, whereas, income support to farmers in the form of the decoupled single farm payment is shown to be most influential in regions with low agricultural land prices.
\end{abstract}

Keywords Land price · Asset pricing · Single farm payment · Quantile regression

JEL Classification Q11 $\cdot \mathrm{Q} 15 \cdot \mathrm{Q} 24 \cdot \mathrm{R} 12$

\section{Standort Determinanten von agrarwirtschaftlichen Landpreisen}

Zusammenfassung Dieses Papier analysiert Determinanten von agrarwirtschaftlichen Landpreisen mit einem besonderen Fokus auf standort-spezifischen Faktoren.

Originally presented at Western Regional Science Association 50th Anniversary meeting, 27 February-2 Mars 2011.

P. Nilsson $(\varangle) \cdot$ S. Johansson Department of Economics, Finance and Statistics, Jönköping International Business School, P.O. Box 1026, 55155 Jönköping, Sweden

e-mail: pia.nilsson@ihh.hj.se

S. Johansson

e-mail: sara.johansson@ihh.hj.se 
Ein asset-pricing Modell wird verwendet um agrarwirtschaftliche Preise in erwartete Erträge von der tatsächlichen Nutzung und der potenziellen Nutzung zu zerlegen. Das Modell wird im inter-regionalen Kontext geschätzt mit erklärenden Faktoren hinsichtlich der regionalen Variationen von agrarwirtschaftlicher Landproduktivität, Subventionen und städtischen Regionen in Beziehung gesetzt werden. Die Resultate zeigen dass sowohl agrarwirtschaftliche wie auch nicht-agrarwirtschaftliche Faktoren entscheidende Determinanten fuer den Preis sind. Anhand der marginalen Effekten zeigt sich dass agrarwirtschaftliche Faktoren in Gemeinden mit hohen Preisen entscheidend sind, wogegen in Gemeinden mit niedrigen Preisen agrarwirtschaftliche Subventionen der wichtigste Einflussfaktor ist.

\section{Introduction}

In this paper we analyse the determinants of Swedish agricultural land prices by decomposing land prices into expected returns from both the agricultural and nonagricultural use of land. In Sweden, prices for agricultural land have been steadily increasing during the last decade and explanations are likely to be related to both agricultural and urbanising factors. Since the accession to the EU and the European common agricultural policy, specific attention has been paid to institutional factors that influence the structure and profitability of the agricultural sector. Especially after the common agricultural policy reform in 2003, and subsequent decoupling of agricultural support payments. However, explanations are also found in factors that are often focal points in studies of urban growth such as regional variations in accessibility to urban and rural amenities (Oltmer and Florax 2001). During the last decades, countries throughout Europe have witnessed a growth in non-agricultural markets in the rural part of the economy, e.g. markets related to tourism, culinary experiences, horse breeding, fishing and hunting activities (Busby and Rendle 2000; Sharpley and Vass 2006). Recent figures show that, in Sweden, rural tourism in combination with farming turns over about 1 billion SEK each year. The growing tourist industry in rural areas suggest that the agricultural landscape is an important prerequisite for nature-based tourism and that owners of agricultural land are faced with a growing set of opportunities for its alternative use. However, not all rural areas are equally attractive. As noted by Walford (2001) and Gannon (1994) location is an important prerequisite for the potential of diversification and non-agricultural use of land. Overall, this suggests that besides traditional agricultural land price determinants that relate to land fertility and income support to farmers, non-agricultural factors such as accessibility to customers, services, employment opportunities and rural amenities are likely to be important determinants of the price of agricultural land.

A large number of papers have empirically explored the importance of various factors determining land prices such as net returns from agriculture (Melichar 1979; Alston 1986; Gardner 1987), payments to support farmers' incomes (Shaik et al. 2005), urbanising influences and site characteristics (Xu et al. 1993; Cavailhès and Wavresky 2003; Bell and Irwin 2002; Irwin and Bockstael 2004; Wu 2001). However, comparatively few papers have combined these approaches and examined agricultural land prices as a function of both agricultural and non-agricultural factors including the effects of decoupled income support to farmers. Moreover, while most of the 
studies that estimate capitalisation of farm support programs conclude that income support do affect agricultural land prices, there is still no consensus on the extent to which capitalisation occur, neither is there sufficient knowledge concerning the regional distributional effects of rural policy.

For the purpose of analysing regional variations in agricultural land price determinants, we estimate an asset-pricing model in which the price of agricultural land is a function of the expected returns from its current agricultural use and its potential future use (Capozza and Helsley 1989; Plantinga et al. 2002). In our application of this model, expected returns from the agricultural use of land is explained by regional variations in land fertility, average size of farms, availability of land and income support to farmers. Spatial characteristics that influence the potential use of agricultural land are related to access to urban and rural amenities. Considering that the potential to find an alternative use for agricultural land is likely to increase with the density of economic activities, we use a measure of population accessibility, designed to reflect the influence of urbanity on agricultural land prices. ${ }^{1}$

Returns from agricultural land are strongly related to locational factors, such as regional variations in the quality and structure of the local agricultural sector, agricultural support payments and the density and structure of other activities in the local economy. Therefore, price determinants are expected to vary significantly across space. In order to identify the underlying factors explaining agricultural land prices we estimate a cross-regional regression model on municipality data. While long timeseries data would be preferable for analysing how price determinants evolve over time, cross-section regional data is interesting for assessing the impacts of regional heterogeneity and explore segments in the agricultural land market. The estimations are conducted using quantile regressions which enable us to examine the influence of price determinants across the distribution of the dependent variable. This is a desirable feature since the natural conditions for agriculture vary significantly across Sweden and the price of agricultural land is highly skewed across municipalities.

Our results show that when we estimate our land price equation conditional on the median; expected returns from both the agricultural and potential non-agricultural use of land are influential determinants of agricultural land prices. However, when we estimate the equation conditional on different quantiles across the dependent variable, the results indicate differences between municipalities with high and low agricultural land prices, respectively. In line with other recent work, the paper find evidence that urban influences are the primary factor inflating land prices at the urban fringe. Results also indicate that the influence of population accessibility and rural amenities are larger in municipalities that have high agricultural land prices.

The analytical approach to geographical distances used in most previous studies is relevant only for land located at the urban fringe. This study contributes to previous research in this area by providing empirical estimates based on a spatial index showing the spatial relation of each location to all urban centra across the country.

The paper is organised in the following way. Section 2 summarises some of the most relevant literature and present the theoretical framework of the paper. Section 3

\footnotetext{
${ }^{1}$ In this paper, the concepts of regions and municipalities are used interchangeably to denote municipalities. There are 290 municipalities in Sweden forming the smallest level of local governments.
} 
describes the data used in the empirical analysis followed by a description of empirical methodology and estimation procedure. The analysis is presented in Sects. 4 and 5 concludes the paper.

\section{Previous studies and theoretical framework}

The market for agricultural land is characterised by the interaction of both agricultural and urbanising factors. The quality of land in terms of its capacity to produce agricultural products is generally regarded as the most important driver of land values. Early approaches, often based on the asset-pricing framework, show that net returns from agriculture, or proxies for net returns, are among the most important determinants of agricultural land prices (Reynolds and Timmons 1969; Melichar 1979; Alston 1986; Gardner 1987). Moreover, a general conclusion in most studies is that differences in the price of agricultural land reflect regional variations in natural prerequisites in terms of soil quality and climate conditions (Miranowski and Hammes 1984; Mendelsohn et al. 1994). In line with this Wu (2001) finds that environmental factors may affect not only the geographic location of economic activities but also their environmental consequences.

Besides natural conditions for agriculture, institutional factors have been shown to play an important role in the determination of land prices (Weersink et al. 1999). Considering that each individual farmer is faced with an opportunity set shaped by both natural prerequisites and institutional settings, the land use options available for a farmer are likely to be conditional upon both natural conditions for agriculture and institutional factors. Various studies have analysed the impact of support schemes on land prices. Such studies commonly show that support payments have a positive influence on agricultural land prices in both US and Canadian land markets (Clark et al. 1993). There is also a significant number of studies that analyse various aspects of decoupled payments with a focus on European land markets. These studies are primarily focused on the influence of the decoupling reform on agricultural production (Rude 2008), investment decisions of farmers (Sckokai and Moro 2009) and income distributional aspects (Latruffe and Mouël 2009). Furthermore, there is some empirical evidence suggesting that decoupled income support have a significant positive influence on the rental price of land (Brady et al. 2009).

Another line of research distinguishes non-agricultural factors tied to location, geography and land conversion to be the most influential determinants of agricultural land prices. The focal points of such papers are the effects of urbanisation in terms of nearness to urban areas, population density and population growth (Shi et al. 1997; Plantinga et al. 2002; Cavailhès and Wavresky 2003) or the influence of site characteristics (Dunford et al. 1985; Xu et al. 1993). It is well-established that distance to towns and cities influence agricultural land prices due to savings in transportation costs for farmers. Thus, the price of land does not only vary with its fertility, but also with its location, suggesting that proximity to markets gives a greater price than land equally fertile in a distant part of the country. Previous empirical studies that examine agricultural land prices as a function of both incomes from agriculture and variables reflecting urban pressure show that urbanising influences play a vital role 
in the determination of agricultural land prices (Clonts 1970; Veldkamp and Lambin 2000).

\subsection{Actual and potential returns from agriculture}

In this paper we apply an asset-pricing model in which the current value of a parcel of land is the sum of expected future income flows discounted according to the risk associated with these flows. Following from the assumptions of perfect competition and perfect foresight, landowners seek to maximise the returns from their land, implying that the market price of a parcel of land should reflect the expected returns from its current use as well as from its potential future use (Plantinga et al. 2002). In this model, current use reflects the present discounted value of expected streams of net returns from agriculture between period $t$ and the point in time $t^{*}$ where land is converted to its alternative use. In a similar way potential use reflects the present value of expected net returns from its alternative use from the date of conversion and onwards. Thus, the market price of a parcel of agricultural land in location $i$ at time $t$ is expressed in Eq. (1).

$$
P_{t, i}^{A}=E_{t, i}\left\{\int_{t}^{t^{*}} A_{i}\left(S_{i}\right) e^{-r(\tau-t)} d \tau+\int_{t^{*}}^{\infty} R_{i}\left(\tau, z_{i}\right) e^{-r(\tau-t)} d \tau-C e^{-r\left(t^{*}-t\right)}\right\}
$$

where $A_{i}$ is net returns from land in its agricultural use in location $i$ and $R_{i}$ is net returns from agricultural land in its potential use in location $i$. Spatial characteristics that reflect expected returns from land in its agricultural use are determined by a vector $S$, and spatial conditions that determine expected returns from the potential use of land are determined by $z$. Furthermore, $\tau$ is a time factor, $C$ is the cost of converting land from one sector to another, and $r$ is the discount rate. Hence, this model decomposes the current value of a parcel of land into two components; $A_{i}$ links the current price to expected returns from the agricultural use of land up to the date of converting the land to its alternative use, and $R_{i}$ links the price to expected returns from its potential use from the date of conversion and onwards.

Following Capozza and Helsley $(1989,1990)$ a fundamental assumption in this model is that land buyers are risk neutral and discount the future at a constant rate. This assumption is further developed in Plantinga et al. (2002) as they show that the inherent spatial and temporal components in the model are additive and separable which implies that the rate of change in development rates is independent of location. For simplicity, we follow this assumption so that conversion costs and interest rates are assumed to be equal across locations. Following from Eq. (1) and the assumptions of perfect competition and perfect foresight, owners of agricultural land convert their land to alternative uses at the point in time where the present value of expected returns is maximised. Implying that Eq. (1) can be simplified to Eq. (2).

$$
P_{t, i}^{A}=E_{t, i} \int_{t^{*}}^{\infty} R_{i}\left(\tau, z_{i}\right) e^{-r(\tau-1)} d \tau+\left(\frac{A_{i}\left(S_{i}\right)}{r}\right)\left(1-e^{-r\left(t^{*}-T\right)}\right)-C e^{-r\left(t^{*}-t\right)}
$$

where the first order condition for a maximum of $P^{A}$ with respect to $t^{*}$ is expressed in Eq. (3).

$$
R_{i}\left(t^{*}, z_{i}\right)-A\left(S_{i}\right)-r C=0 .
$$


Equation (3) implies that the present value of expected returns from a given parcel of land is maximised when land is converted from its agricultural to its potential use. This occurs at a point in time when returns from land from the alternative use is equal to the value of its agricultural output $A\left(S_{i}\right)$ plus the cost of conversion $r C$. Considering that returns from agriculture as well as returns from agricultural land in its alternative use are expected to depend on the location of land, the first order condition in Eq. (3) implicitly defines the points in space where the conversion of land from agricultural to alternative use has expected positive returns.

In accordance with models of urban growth (Arnott and Lewis 1979; Arnott 1980; Capozza and Helsley 1989, 1990; Anas et al. 1998), we assume that population size is the main condition for Eq. (3) to hold. This implies that landowners are presumed to make intertemporal land use decisions conditional on expectations over changes in land rents due to population growth

\subsection{Accessibility and the potential use of land}

Spatial characteristics that affect the potential use of agricultural land are related to factors such as accessibility to customers, services and employment opportunities. In particular, the potential to find alternative use for agricultural land is likely to increase with the density of economic activities in the surrounding geography (Cavailhès and Wavresky 2003). In our measurement of accessibility, the idea of the functional urban region (FUR) is a central concept. A FUR is distinguished by its concentration of activities and its infrastructure, which facilitate a particularly high interaction frequency within its borders. In particular, a FUR is characterised by being an integrated regional labour market, i.e. a commuting region.

From the perspective of a given location within a FUR, there are three relevant types of travel: short local travel, travel within the FUR and travel to locations in all other regions.

This implies that for any kind of opportunity three relevant measures of geographical accessibility can be calculated: local, intra-regional and inter-regional accessibility. Following Johansson et al. (2002) we can define the geographical accessibility of municipality $i(i=1, \ldots, n)$ to opportunity $D$ within the own municipality and in the $n-1$ surrounding municipalities according to Eqs. (4a)-(4c).

$$
\begin{aligned}
& \text { Local accessibility: } \quad z_{L i}^{D}=\exp \left\{-\lambda_{1} t_{i i}\right\} D_{i} \\
& \text { Intra-regional accessibility: } \quad z_{I R i}^{D}=\sum_{j \in M, j \neq i} \exp \left\{-\lambda_{2} t_{i j}\right\} D_{j} \\
& \text { Inter-regional accessibility: } \quad z_{E R i}^{D}=\sum_{k \notin M} \exp \left\{-\lambda_{3} t_{i k}\right\} D_{k} .
\end{aligned}
$$

Equations (4a-(4c) show that local accessibility is the sum of each municipality's internal accessibility to opportunity $D$, intra-regional accessibility refers to the sum of each municipality's accessibility to opportunity $D$ in all other municipalities within its own functional region $M$, and inter-regional accessibility is the municipality's accessibility to opportunity $D$ in all locations outside region $M$. Thus, $t_{i i}$ is the average 
travel time inside municipality $i$ and $t_{i j}$ is the average travel time distance between municipality $i$ and $j$. Moreover, $\lambda$ is a pre-estimated time-sensitivity parameter, reflecting how increasing travel time efforts reduce the accessibility.

Johansson et al. (2003) estimate different time sensitivity parameters $\lambda$ for local, intra-regional and inter-regional interaction. Inside a municipality parameter $\lambda_{1}$ applies, inside the pertinent region parameter $\lambda_{2}$ applies and for contacts outside the own functional region parameter $\lambda_{3}$ applies. These parameters differ in size in the following way: $\lambda_{2}>\lambda_{3}>\lambda_{1}$, which means that the time friction is greater for intraregional travels than it is for inter-regional travel and smallest for short distances within a municipality $i$. Hence, the accessibility of a given municipality is defined as the sum of its internal accessibility to the opportunity $D_{i}$, and its accessibility to opportunity $D_{j}$ in all other municipalities $(j \neq i)$.

Thus, the opportunity variable $D_{j}$ may represent the size of possible contacts that can be made in location $j$, while $\exp \left\{-\lambda t_{i j}\right\}$ is a distance discount operator which reduces the value of $D_{j}$ as the travel time efforts, $t_{i j}$, increase.

The mathematical properties of the three types of accessibilities presented in Eqs. (4a)-(4c) allow for the aggregation of them to one aggregate measure that reflects the total accessibility of location $i$ to all other locations within the relevant geographical boundaries (in this case, the national borders of Sweden), expressed in Eq. (5). ${ }^{2}$

$$
z_{i}^{D}=z_{L i}^{D}+z_{I R i}^{D}+z_{E R i}^{D} .
$$

In Eq. (5), the three accessibility measures are additively combined to obtain one single measure. Assuming that the potential to find an alternative use for agricultural land is likely to increase with population size in the surrounding geography, the accessibility measure used in this paper is calculated with respect to the size of the population in each municipality $(D)$. This measure has the advantage of capturing the distance to all locations where economic activities are concentrated. Specifically, the accessibility of a location reflects the mass of different types of opportunities (employment, services and other urban amenities) that can be reached from one location, given the cost of travelling from this location to other points in space. Hence, Eq. (5) measures how one location is spatially related to all other locations with respect to population size, and reflects the choice context of spatial interaction when spatial interaction costs are taken into account.

According to Capozza and Sick (1994), asset-price models that deal with options on real assets should include a net growth premium such that the price of land increases with the growth rate of urban rents and risk. Considering that net growth variables such as growth in population and residential land use are highly correlated with the density of economic activity in different locations, such a growth premium is implicitly captured by our measure of population accessibility. This follows from the fact that the larger accessibility a location has to various economic activities in the own region as well as in surrounding regions, the greater its growth potential.

\footnotetext{
${ }^{2} \mathrm{An}$ accessibility of this type should satisfy certain criteria of consistency and meaningfulness. It should be emphasised that the expressions in Eqs. (4a)-(4c) satisfies such warranted criteria (Weibull 1976). An accessibility of this type is also consistent with a measure of market potential introduced by Harris (1954).
} 


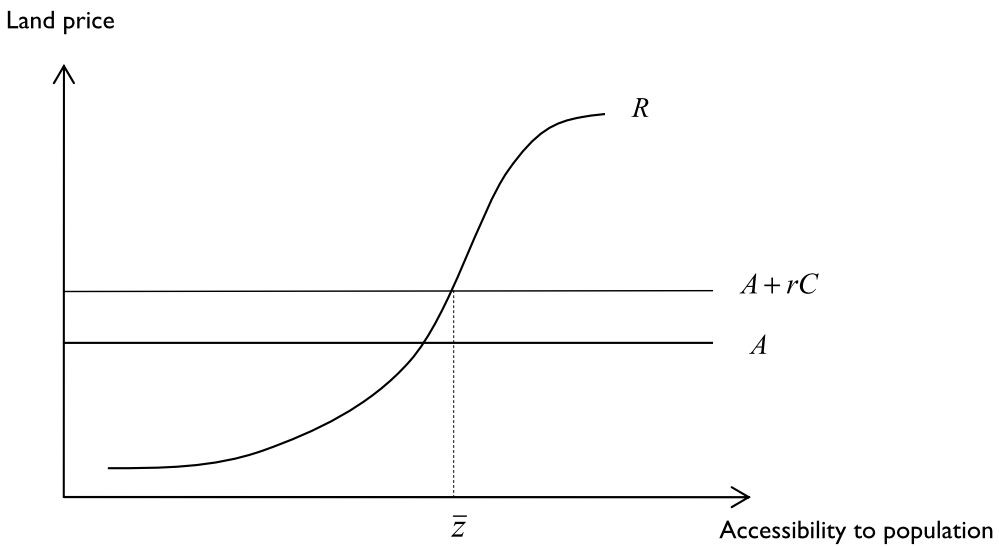

Fig. 1 Returns from land in agricultural and non-agricultural use

Moreover, the representation of space implicitly captured in this measure of accessibility reflects the potential of physical interaction between localities, and infers that spatial autocorrelation should be reduced. As shown by Andersson and Gråsjö (2009), this representation of space, where spatial dependencies are modelled through spatially lagged explanatory variables, are able to account for spatial dependence among observations.

Figure 1 shows the relationship between our measure of accessibility and returns from land in agricultural and alternative use at a given point in time. As shown in the graph, the expected returns from land in its alternative use increases with accessibility to population as illustrated by the $S$ shaped sigmoid curve. In locations with poor accessibility conditions, the expected returns from agricultural land in its alternative use low, whereas in vicinity of point $\bar{z}$ returns from the alternative use of land begin to exceed the returns from its agricultural use. In locations where accessibility conditions are sufficiently good, returns from land in its alternative land use is large enough to cover both the opportunity cost of agricultural use once the land is converted, and the cost of conversion. In such locations profit maximising landowners will convert agricultural land to its alternative use. Hence, only in locations with accessibility conditions in the vicinity of point $\bar{z}$, returns from alternative use are expected to inflate agricultural land prices. In locations with an accessibility that is higher than $\bar{z}$, land is already converted and has a higher value than land in agricultural use due to the accessibility premium. However, very sparsely populated areas are attractive for some type of activities, implying that the relation between accessibility and land price can be depicted by a more $U$ shaped relation. In such case, the potential for alternative land uses rise not only with accessibility to urban attributes, but also with the sparseness characterising the most peripheral regions. From a Nordic perspective, the most peripheral rural areas exhibit poor accessibility conditions, have extremely low population densities, climatic disadvantages and unfavourable conditions for agricultural use of land. Non-agricultural use of land in these areas is dominated by tourism based on nature and wildlife. The observed geographical patterns of prices of agricultural land in Sweden do not indicate that this type of activities represents an alternative use for agricultural land that increases land prices in the most sparsely populated areas. 


\section{Data and empirical model}

For the purpose of explaining the influence of agricultural and non-agricultural factors on agricultural land prices we apply a cross-regional regression model. The research unit is municipalities and the dependent variable is the average municipal per hectare price of agricultural land. The degree to which Swedish agricultural land prices are observable across municipalities is limited and Swedish Official Statistics report annual agricultural land prices at either county or NUTS level. Moreover, comparatively few sales of exclusively agricultural land occur each year and most sales include a residential unit in combination with other types of farm buildings and their pertaining land. To obtain the per hectare price of agricultural land at a municipality level we utilise a sample of 11000 farm transactions, across Sweden. These data are obtained from the Swedish Mapping, Cadastral and Land Registration Authority, and include transactions from the period January 2007 to December 2008. After deleting observations with missing value on key variables (sales price and farm size) and including only such transactions that are representative and include at least one hectare of agricultural land, the sample size reduces to 8000 farm sales. ${ }^{3}$

To obtain the municipal per hectare price of agricultural land from this sample we follow the approach taken by Statistics Sweden such that the value of land is obtained by deducting the value of structure. Since tax assessment values are available in the data base we calculate the value of land based on the assumption that the price of agricultural land in relation to the purchase price is the same as the tax assessment value of agricultural land in relation to the total tax assessment value. Hence, this sample of farm level observations across the country allow us to estimate a mean price of agricultural land for 269 out of 290 Swedish municipalities as illustrated in Fig. 2.

\subsection{Explanatory variables}

Expected returns from the agricultural use of land are represented by the vector $S$ (see Eq. (1)) and contain variables that explain regional variations in the quality and availability of agricultural land. In contrast to the large body of empirical studies that focus on net farm income, this analysis follows the recommendations of Melichar (1979), who points out that pure land productivity factors are more relevant determinants than are observed farm incomes. Another kind of cash flow related to the agricultural use of land is different types of government support to the agricultural sector. Differences in the regional distribution of agricultural support payments are mainly related to the nature and productivity of the land, and the agri-environmental concerns related to agricultural production. Accordingly, two types of agricultural support payments are included in the analysis. First is, the single farm payment, which gives a fixed direct payment to owners of agricultural land, conditional only upon the preservation of the

\footnotetext{
${ }^{3}$ Representative transactions are those that have a sales price coefficient larger than 0.6 or lower than 6 . The sales price coefficient is calculated as the sales price divided by the tax assessment value. A total of 800 farm transactions fall out of this range. This method of calculating land prices is consistent with the methods used by the Swedish Board of Agriculture and Statistics Sweden.
} 
Fig. 2 Quantile distribution of average municipal price of agricultural land measured in $€$ (based on sales during 2007-2008)

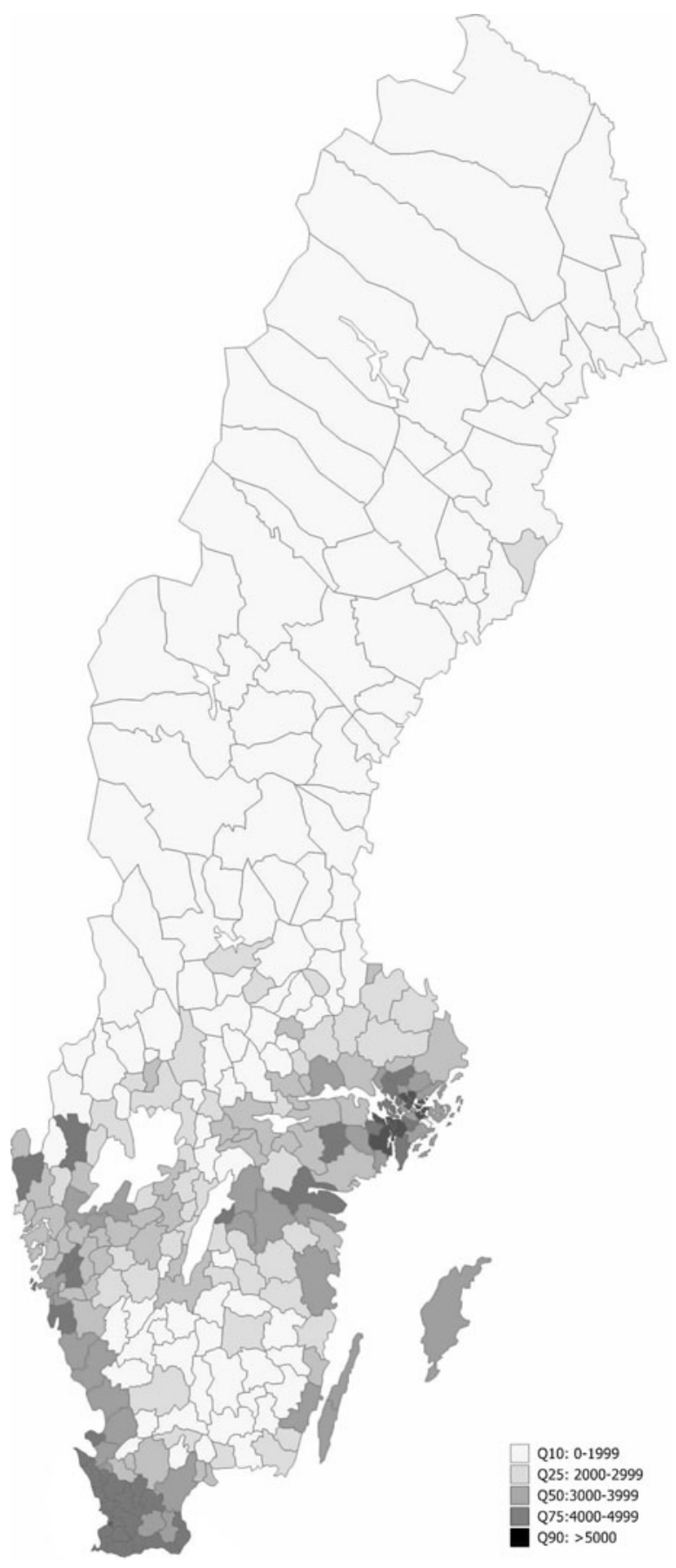


land in an arable state. ${ }^{4}$ Following from the theoretical section and results obtained in previous empirical studies, we predict income support in the form of the single farm payment to have a positive influence on land prices.

Support payments that are more related to the actual use of land for agricultural production take the form of various payments for the protection and preservation of the agricultural environment. Agri-environmental payments include support for the preservation of semi-natural pastures and mown meadows, open pasture and the preservation of cultural heritage, among other things. The amount of agricultural environmental payments to farmers in each municipality depends on the characteristics of the environment in the municipality. Considering that sensitive environments tend to be more difficult to cultivate, it is not evident that these payments have a positive influence on land prices. Previous studies have shown that the conditionality of these types of support payments can offset the benefits due to increased maintenance expenses (Rutherford and Whalley 1990). Furthermore, regulations surrounding the use of farmland in conjunction with agrarian heritage sites might result in some farmland being removed from production. Thus, the predicted sign of the parameter estimate is ambiguous and ultimately depends on whether farmers are overor undercompensated for the costs of cultivating land located in sensitive environments.

Besides accessibility to urban areas and the supply of goods, services and amenities found in such locations, the price of agricultural land also depends on the quality and structure of site characteristics (Xu et al. 1993; Wu 2001; Irwin 2010). In this paper, we use the number of seasonal homes in each municipality as a proxy for amenities in the municipalities rural areas. There are 500000 second homes in Sweden and a majority of these homes are located in rural amenity-rich areas.

Explanatory variables are presented in Tables 1 and 2 presents the descriptive statistics.

\subsection{Empirical model}

Following the basic relationship between expected returns and land prices at a given point in time presented in Eqs. (1)-(3), the empirical approach in this paper is to estimate how different kinds of location-specific factors influence the mean price of market sold agricultural land. Sweden is a country that stretches over many different climate zones, and coniferous forests dominate the northern parts of the country. Consequently, the natural conditions for agriculture vary significantly across regions. The implication of this is that our dependent variable has a skewed distribution across municipalities, as shown in Fig. 2 (and Table 2). This suggests that the impact of the explanatory variables may vary along the distribution of the dependent variable. Since Ordinary Least Square regressions estimate the conditional mean of the dependent variable as a function of the explanatory variables, this estimation method does not account for the possibility that the estimated effects of the covariates differ across

\footnotetext{
${ }^{4}$ This is the largest support measure to farmers in the EU and the size of this payment depends on historical farm yields during a reference period. Since the CAP reform of 2003, this direct payment is entirely decoupled from production.
} 
Table 1 Variables and their definitions

\begin{tabular}{|c|c|c|}
\hline Variable* & Description & Motivation \\
\hline $\begin{array}{l}\text { Agricultural land } \\
\text { price }\end{array}$ & $\begin{array}{l}\text { The log of the average municipal per } \\
\text { hectare price of agricultural land }\end{array}$ & Regressand \\
\hline Land fertility & $\begin{array}{l}\text { The log of average yields in } \mathrm{kg} \text { of cereals } \\
\text { and grains per hectare }\end{array}$ & $\begin{array}{l}\text { Indicate expected net returns from } \\
\text { agriculture in a given municipality }\end{array}$ \\
\hline Pasture & $\begin{array}{l}\text { Share of agricultural land that consists of } \\
\text { pastures and meadows }\end{array}$ & $\begin{array}{l}\text { Indicate natural prerequisites for } \\
\text { agriculture i.e. the share of total land in } \\
\text { each region not suitable for cultivation }\end{array}$ \\
\hline $\begin{array}{l}\text { Average farm } \\
\text { size }\end{array}$ & Average size of farms in terms of hectares & $\begin{array}{l}\text { Indicate the presence of scale economies } \\
\text { in the agricultural sector }\end{array}$ \\
\hline $\begin{array}{l}\text { Volume of } \\
\text { activity }\end{array}$ & $\begin{array}{l}\text { Share of agricultural land that is sold during } \\
\text { the period }\end{array}$ & $\begin{array}{l}\text { Indicate volume of activity in the land } \\
\text { sales market; } \\
\text { a. Reflect that the opportunity to buy land } \\
\text { is occasional which might bid up the price } \\
\text { for land } \\
\text { b. Reflect aversion towards investing in } \\
\text { agricultural land if it cannot be used for } \\
\text { activities other than agriculture }\end{array}$ \\
\hline $\begin{array}{l}\text { Single farm } \\
\text { payments }\end{array}$ & $\begin{array}{l}\text { The log of the amount of single farm } \\
\text { payments received by farmers in a given } \\
\text { municipality }\end{array}$ & $\begin{array}{l}\text { Indicate expected returns from income } \\
\text { support payments }\end{array}$ \\
\hline $\begin{array}{l}\text { Agri- } \\
\text { environmental } \\
\text { payments }\end{array}$ & $\begin{array}{l}\text { The log of the amount of } \\
\text { agri-environmental payments received by } \\
\text { farmers in a given municipality }\end{array}$ & $\begin{array}{l}\text { Indicate expected returns from } \\
\text { agri-environmental support payments }\end{array}$ \\
\hline $\begin{array}{l}\text { Accessibility to } \\
\text { population }\end{array}$ & $\begin{array}{l}\text { The log of accessibility to population } \\
\text { defined in Eq. (5) }\end{array}$ & $\begin{array}{l}\text { Indicate expected returns from the } \\
\text { potential to find an alternative use of } \\
\text { agricultural land }\end{array}$ \\
\hline Rural amenities & $\begin{array}{l}\text { The log of the number of seasonal homes } \\
\text { used as a proxy for amenities in the } \\
\text { municipality's rural areas }\end{array}$ & $\begin{array}{l}\text { Indicate expected returns from the } \\
\text { potential to find an alternative use of } \\
\text { agricultural land }\end{array}$ \\
\hline
\end{tabular}

*Data on agricultural factors are obtained from the Swedish Board of Agriculture (land fertility, pasture and support payments), non-agricultural factors and land sales are obtained from Statistics Sweden and the Swedish Mapping, Cadastral and Land Registration Authority. Explanatory variables are measured in 2008

the distribution of the dependent variable. As a solution Koenker and Basset (1978) originally proposed quantile regressions as an alternative to OLS. Moreover, Gould (1992) and Gråsjö (2006) suggest a bootstrap re-sampling procedure for estimating standard errors in estimations with heteroscedastic error distributions.

Quantile regressions are appealing to the study of land price determinants providing a more complete description of the influences of agricultural and non-agricultural factors on land prices since across the distribution of the dependent variable. The regression coefficients of different conditional quantiles are estimated with different weights given to the residuals. In the median regression, all residuals receive an equal weight, whereas negative residuals are given weights of 0.10 and 0.25 and positive residuals weights of 0.75 and 0.90 when estimating the different percentiles.

Following Gould (1992) the $\theta$ th conditional quintile of our dependent variable $\left(P_{i}^{A}\right)$ given $x_{i}$ is $Q_{\theta}\left(P_{i}^{A} \mid x_{i}\right)$, and the quantile regression estimate of $\beta_{\theta}$ is the value 
Table 2 Descriptive statistics

\begin{tabular}{|c|c|c|c|c|c|c|}
\hline & Min. & Max. & Mean & $\mathrm{SD}$ & Skewness & Kurtosis \\
\hline $\begin{array}{l}\text { Per hectare price } \\
\text { of agricultural } \\
\text { land (in Euros) }\end{array}$ & 152 & 187859 & 6847 & 16236.5 & 0.8 & 8.4 \\
\hline Land fertility & 1920 & 6153 & 3792 & 1107 & 0.01 & -1.1 \\
\hline Pasture & 0.0 & 1.0 & 0.2 & 0.1 & 1.8 & 7.5 \\
\hline $\begin{array}{l}\text { Average Farm } \\
\text { size }\end{array}$ & 1.0 & 201 & 41.07 & 24.4 & 1.8 & 6.8 \\
\hline $\begin{array}{l}\text { Volume of } \\
\text { activity }\end{array}$ & 1 & 227 & 29.5 & 27.0 & 2.6 & 11.6 \\
\hline $\begin{array}{l}\text { Single farm } \\
\text { payments (in } \\
\text { Euros) }\end{array}$ & 92 & 581 & 218 & 56.0 & 0.2 & 1.0 \\
\hline $\begin{array}{l}\text { Agricultural } \\
\text { environmental } \\
\text { payments (in } \\
\text { Euros) }\end{array}$ & 21 & 1359 & 115 & 98.9 & 0.8 & 10.4 \\
\hline $\begin{array}{l}\text { Accessibility } \\
\text { conditions }\end{array}$ & 3485 & 818374 & 106656 & $1.24 \mathrm{E} 5$ & 2.8 & 9.0 \\
\hline Rural amenities & 6 & 24213 & 1428 & 2046.5 & 6.4 & 61.1 \\
\hline
\end{tabular}

of $\beta_{\theta}$ that minimises the sum of the absolute deviations residuals according to Eq. (6).

$$
\min _{\beta} \frac{1}{n}\left(\sum_{P_{i}^{A}>x_{j, s}^{\prime} \beta}\left|P_{i}^{A}-x_{i}^{\prime} \beta\right| \theta+\sum_{P_{i}^{A}<x_{j, s}^{\prime} \beta}\left|P_{i}^{A}-x_{i}^{\prime} \beta\right|(1-\theta)\right) .
$$

For the $\theta$ th quantile $(0<\theta<1)$ our regression model is expressed in Eq. (7).

$$
\ln P_{i}^{A}=\beta_{\theta} \ln X_{i}^{\prime}+\varepsilon_{\theta, i}
$$

where $\ln P_{i}^{A}$ is the $\log$ of the average municipal per hectare price of agricultural land in municipality $i, \beta_{\theta}$ is the unknown vector of regression parameters associated with the $\theta$ th quantile and $\mu_{\theta, i}$ is the error term associated with that quantile. For simplicity $\ln \mathrm{X}_{i}^{\prime}$ represents a vector containing both the agricultural and non-agricultural factors in each municipality as reported in Table 1. Equation (7) is estimated using a double $\log$ form to control for skewed distributions of explanatory variables.

\section{Regression results}

Regression results are reported in Tables 3 and 4. In a first step, we estimate the model conditional on the median and in three different specifications. In a second step we estimate quantile regressions to examine the relative importance of explanatory variables at different points of the distribution of the dependent variable. Before turning to the interpretation of the results a discussion on multicollinearity and 
Table 3 Results from median regressions

\begin{tabular}{lccc}
\hline Parameter & \multicolumn{2}{l}{ Coefficient (robust std. err.) } \\
\cline { 2 - 4 } & 1. & 2. & 3. \\
\hline Land fertility & $1.835^{* * *}(0.199)$ & $1.044^{* * *}(0.176)$ & $0.927^{* * *}(0.192)$ \\
Pasture & $-0.057(0.362)$ & $-0.548^{*}(0.307)$ & $-0.711^{* *}(0.300)$ \\
Average farm size & $0.093(0.167)$ & $0.069(0.087)$ & $0.103(0.079)$ \\
Volume of activity & $-0.420^{* * *}(0.060)$ & $-0.549^{* * *}(0.307)$ & $-0.124(0.076)$ \\
Single farm payment & & $0.759^{* * *}(0.134)$ & $0.544^{* * *}(0.179)$ \\
Agri-envir. payments & & $-0.432^{* * *}(0.083)$ & $-0.381^{* * *}(0.091)$ \\
Accessibility to pop. & & & $0.293^{* * *}(0.063)$ \\
Rural amenities & & $-0.450(1.361)$ & $0.060^{*}(0.034)$ \\
Intercept & $-3.822^{* * *}(1.277)$ & 0.468 & $-2.455(1.560)$ \\
Pseudo $R$ square & 0.415 & 51.641 & 0.514 \\
Condition number & 32.753 & & 58.792 \\
Sample size = 269 & & &
\end{tabular}

${ }^{*} 0.1,{ }^{* *} 0.05,{ }^{* * *} 0.01$. Dependent variable; the log of average municipal per hectare price of agricultural land. Bootstrap standard errors in parenthesis

how this may affect the interpretation of our results is necessary. Significant correlations among the regressors mainly arise between variables that measure land fertility, support payments and accessibility to population. The relationships between these variables are somewhat straightforward. Since the size of the single farm payment depends on the value of farm output over a reference period, there is a positive correlation between land fertility and the amount of single farm payment per hectare (0.63). There is also a positive correlation between land fertility and the density of population since $(0.46)$ people historically have settled in places where the cultivation of land is relatively easy and yields are comparatively high. There is also a significant correlation between land fertility and the amount of agri-environmental support paid per hectare. However, this relationship is negative, indicating that agricultural land in sensitive environments is less productive. To strengthen the interpretation of our results and examine robustness in coefficient estimates we estimate the model in three different specification and report the estimated condition number based on the spread in eigenvalues. Generally, if the condition number is less than 100 , there is no serious problem with multicollinearity, while condition numbers between 100 and 1000 imply moderate to strong multicollinearity (Montgomery et al. 2001).

Regression results are reported in Tables 3 and 4. The first specification includes only agricultural variables, whereas support measures and urbanising influences are excluded. The second specification includes support measures, and the variables reflecting rural amenities and accessibility to population are included together with agricultural and support variables in the third specification. 
Table 4 Results from quantile regressions

\begin{tabular}{|c|c|c|c|c|c|}
\hline \multirow[t]{2}{*}{ Parameter } & \multicolumn{5}{|c|}{ Coefficient (robust std. err.) } \\
\hline & 0.10 & 0.25 & 0.50 & 0.75 & 0.90 \\
\hline \multirow[t]{2}{*}{ Land fertility } & 0.339 & $0.700^{* *}$ & $0.927^{* * *}$ & $0.621^{* *}$ & 0.844 \\
\hline & $(0.279)$ & $(0.214)$ & $(0.192)$ & $(0.304)$ & $(0.552)$ \\
\hline \multirow[t]{2}{*}{ Pasture } & -0.178 & -0.193 & $-0.711^{* *}$ & $-1.175^{* *}$ & -1.681 \\
\hline & $(0.416)$ & $(0.402)$ & $(0.300)$ & $(0.518)$ & $(1.079)$ \\
\hline \multirow[t]{2}{*}{ Average farm size } & 0.128 & $0.168^{* *}$ & 0.103 & 0.100 & 0.166 \\
\hline & $(0.128)$ & $(0.083)$ & $(0.079)$ & $(0.135)$ & $(0.188)$ \\
\hline \multirow[t]{2}{*}{ Volume of activity } & $-0.188^{* *}$ & $-0.156^{*}$ & $-0.124^{* *}$ & -0.089 & 0.075 \\
\hline & $(0.084)$ & $(0.089)$ & $(0.076)$ & $(0.105)$ & $(0.169)$ \\
\hline \multirow[t]{2}{*}{ Single farm payment } & $0.635^{* *}$ & $0.543^{* * *}$ & $0.544^{* * *}$ & $0.468^{* *}$ & 0.087 \\
\hline & $(0.309)$ & $(0.206)$ & $(0.179)$ & $(0.194)$ & $(0.330)$ \\
\hline \multirow[t]{2}{*}{ Agri-envir. payments } & $-0.330^{* * *}$ & $-0.253^{* *}$ & $-0.381^{* * *}$ & $-0.428^{* *}$ & -0.241 \\
\hline & $(0.113)$ & $(0.127)$ & $(0.091)$ & $(0.194)$ & $(0.271)$ \\
\hline \multirow[t]{2}{*}{ Accessibility to pop } & $0.430^{* * *}$ & $0.391^{* * *}$ & $0.293^{* * *}$ & $0.332^{* *}$ & $0.506^{* * *}$ \\
\hline & $(0.082)$ & $(0.077)$ & $(0.063)$ & $(0.129)$ & $(0.160)$ \\
\hline \multirow[t]{2}{*}{ Rural amenities } & 0.057 & 0.052 & $0.060^{*}$ & $0.104^{* *}$ & $0.114^{* *}$ \\
\hline & $(0.056)$ & $(0.043)$ & $(0.034)$ & $(0.129)$ & $(0.076)$ \\
\hline \multirow[t]{2}{*}{ Intercept } & -0.688 & -2.997 & -2.455 & 0.505 & -2.012 \\
\hline & $(2.320)$ & $(2.242)$ & $(1.560)$ & $(3.00)$ & $(4.523)$ \\
\hline Pseudo $R^{2}$ & 0.565 & 0.515 & 0.514 & 0.482 & 0.431 \\
\hline Condition number & 33.12 & 37.36 & 58.792 & 28.65 & 51.2 \\
\hline Sample size $=269$ & & & & & \\
\hline
\end{tabular}

Denote significance at the ${ }^{*} 0.1,{ }^{* *} 0.05$ and ${ }^{* * *} 0.01$ level. Dependent variable; the log of average municipal per hectare price of agricultural land. Bootstrap standard errors in parenthesis

\subsection{The influence of agricultural and non-agricultural factors}

The results show that conditional on the median, both agricultural and nonagricultural factors are important determinants of agricultural land prices. The quality of land measured in terms of land fertility has a positive and significant impact on the price of agricultural land in all three specifications. However, the parameter value is significantly lower when including the availability of land and support payments, indicating that a part of the explanatory power of this variable is picked up by parameters that measure volume of activity in the land market and income support to farmers. In line with expectations, the pastures share of total agricultural land in the municipality has a negative and significant coefficient estimate in the fully specified model, reflecting that the marginal effect of increasing the amount of land not suitable for cultivation has a negative influence on agricultural land prices. Turning interest to the variables measuring income support to farmers, we find some evidence that the single farm payment has a positive impact on agricultural land prices in the fully specified model. After controlling for 
both accessibility conditions and rural amenities, the estimated elasticity of the single farm payment is 0.54 , indicating that a doubling of this subsidy would increase land prices by about 54 per cent. The sign and the magnitude of the coefficient are in line with previous studies showing that decoupled payments translate into higher land values, generally with an elasticity less than 1 (Clark et al. 1993; Weersink et al. 1999; Latruffe and Mouël 2009).

Agricultural environmental payments, by contrast, have a negative influence on land prices. The estimated coefficient is shown to be -0.381 in the fully specified median regression model. This implies that the marginal effect of increasing the amount of environmental payments to a given municipality has a negative influence on the price of agricultural land. This could indicate that municipalities that receive large amounts of agri-environmental support have sensitive environments with high natural and cultural values which are difficult to cultivate, which is reflected in the price of land. Similar results has been found in previous studies. Rutherford et al. (1990) show that conditionality associated with government support programs makes the assessment of their capitalisation diluted. In particular, they argue that these results can be explained by additional costs imposed by complying with set-aside requirements such that farmers may not be compensated for the additional benefits from price supports. In line with these findings, our results suggest that farmers are not overcompensated for preservation efforts tied to agri-environmental payments. The fully specified model also includes accessibility to population and rural amenities among the covariates, reflecting the population density or urbanity of the municipality, and the presence of amenities in the municipality's rural areas. Accessibility has the anticipated positive sign and is significant in the fully specified model. The estimated elasticity of population accessibility shows that an increase in accessibility by 1 per cent, through population growth or improved infrastructure that reduces traveltimes within and between municipalities, results in an increase in agricultural land prices by 0.30 per cent. Second, the number of seasonal homes, presumed to reflect rural amenities, is positive and significant in the fully specified model. Finally, the Pseudo $R^{2}$-values shown in Tables 3 and 4 indicate that the explanatory power of the regression model increases when more explanatory variables are included. This implies that both agricultural and non-agricultural influences add to the understanding of agricultural land price determinants. ${ }^{5}$

\subsection{The influence of agricultural and non-agricultural factors across quantiles}

While the results obtained in Table 3 may serve as a useful benchmark of estimates conditional at the median, this regression technique do not take full account of regional heterogeneity. Since the average price of agricultural land is highly skewed across Sweden due to variances in climate and accessibility conditions, there is also

\footnotetext{
${ }^{5}$ It should be noted that the Pseudo $R^{2}$-values shown in Tables 3 and 4 cannot be directly translated into ordinary $R^{2}$-values based on the sums of squares from OLS regressions. However, as shown by Veall and Zimmermann (1996) the degree of variability between the OLS $R^{2}$ and the Pseudo $R^{2}$ values is small and both can be used to estimate the underlying explanatory power of the model accurately. Having this in mind, it is obvious that the model becomes more accurate the more variables are included.
} 
the possibility that median regression results are biased. Quantile regression allow us to examine the influence of explanatory variables at different point of the distribution of the dependent variable, providing a more complete picture of price determinants. Moreover, it enables us to explore the robustness of median regression results across the distribution of the dependent variable. Table 4 report the results of estimating land price determinants using conditional quantile regressions.

While most of the parameters associated with the agricultural and potential use of land are shown to be robust across the distribution, there are some indications of regional heterogeneity with regards to differences in the magnitudes of estimated parameters. The only regression coefficient that has a significant estimate across the complete distribution is accessibility to population, designed to reflect the influence of urbanity of the municipality and the neighbourhood. The estimated parameter value for this variable is highest for the upper parts of the distribution of the dependent variable, indicating that the potential to find alternative use of agricultural land is larger in regions where agricultural land prices are relatively high. As shown in Fig. 1, agricultural land prices are the highest in urban municipalities and municipalities located in urban interfaces. In line with other recent work, these results provide evidence that urban influences are the primary factor inflating land prices at the urban fringe (Shi et al. 1997; Cavailhès and Wavresky 2003). In line with this, the coefficient estimate of rural amenities, measured as the number of seasonal homes presumed to reflect the quality of amenities in the municipality's rural areas, is positive and significant at the median point in the distribution and the upper quantiles (0.75 and 0.90). As can be seen from Table 4, the estimated elasticity reflecting rural amenities increases its value from the median point in the distribution and to the highest quantile (0.90) from 0.060 to 0.114 , respectively. Thus, the positive impact of rural amenities is mostly prevalent in municipalities where agricultural land prices are comparatively high.

Turning to variables that measure the potential to obtain returns from the agricultural use of land. The marginal effect of improved land quality in terms of increased yields is shown to be significant and influential at the median point in the distribution and at the 25 th and 75 th quantiles. Moreover, the coefficient reflecting volume of activity in the land sales market is negative and significant in the lower and median quantiles. These results could indicate risk aversion towards investing in land if it cannot be used for activities other than agriculture or risk aversion towards investing in land of low quality. Whereas, urban influences and site characteristics and their influence on land prices have been the subject of prior studies, the novel results of this paper concerns regional heterogeneity of the impacts of support payments with respect to differences in land prices.

The estimated coefficients of the single farm payment show that the size of the single farm payment has a positive impact on agricultural land prices at all observed points across the distribution except for the highest quantile. Moreover, the single farm payment, which is a direct transfer of income to land-owners, conditional only upon preservation of the land in an arable condition, seems to be most influential in municipalities with relatively low land prices. It should be noted that the restricted availability of land sales data at a municipality level prevents us from analysing how land prices respond to changes in income support payments over time. Municipalities that receive a large amount of income support are generally also those that have 
the highest yields. Nevertheless, it is evident that our results indicate a significant relationship such that a substantial part of income support in the form of the single farm payment translate into higher land values. It is also evident from the results that the largest leakages of the single farm payment to landowners occur in municipalities characterised by low agricultural productivity and unfavourable conditions for agriculture. These results reinforces the findings in Gelan and Schwarz (2008), that the incidence of subsidies is dependent on the size of the support payment in relation to both agricultural and non-agricultural return factors. Moreover, from the results reported in Tables 3 and 4 our results could also indicate that agricultural land prices are generally more responsive to market-based returns than to government based returns. The elasticity of land fertility is higher than that of income support both in the median regression model and across quantiles. Studies have usually found the opposite relation with some exceptions (Shaik et al. 2005; Weersink et al. 1999). Given the cross-regional approach used in this study, it is difficult to make conclusion about the relative importance of different variables since they are often correlated with each other in static state. Still, the results clearly show that both agricultural and non-agricultural factors influence land prices. These aspects are important for the understanding of land development where option values associated with irreversible and uncertain land development capitalise into agricultural land prices.

\section{Conclusions}

With the results obtained in this paper we are able to confirm several well-known facts and observed patterns relating to location-specific factors and land prices. We are also able to shed light on regional heterogeneity in land price determinants, which have not been extensively studied in the literature. We apply an asset-pricing model and decompose the price of agricultural land into expected returns from both its agricultural and potential use (Capozza and Helsley 1989, 1990; Plantinga et al. 2002). A Quantile regression approach allows us to examine the relative importance of explanatory variables at different point of the distribution of the dependent variable, providing a more complete picture of price determinants. Results confirm that agricultural land prices are strongly related to locational factors, such as regional variations in the quality and structure of the local agricultural sector, agricultural support payments and the density and structure of other activities in the local economy. Overall, when we estimate our land price equation conditional on the median; expected returns from both the agricultural and potential use of land are shown to be influential determinants to agricultural land prices. However, when the equation is estimated across the distribution of the dependent variable, the results show some differences between municipalities with high and low agricultural land prices.

In accordance with a large body of previous research this study shows that direct income support to farmers in the form of the single farm payment has a positive impact on agricultural land prices at all observed points across the distribution except for the highest quantile. The positive effect of single farm payments on agricultural land prices implies that this policy measure works in such way that it increases the 
wealth of landowners rather than increasing the income of farmers. Moreover, the results suggest that these effects are most influential in municipalities with relatively low land prices.

Another interesting finding is that environmental payments that are conditional upon preservation and maintenance of biological values, have a consistent and negative coefficient across the estimations. As discussed, environmental payments are conditional upon preservation and therefore a sustainable use of such land in agricultural production is associated with additional costs, which the support payments are supposed to reimburse. The consistent negative coefficient reflect that municipalities that receive a lot of support for agri-environmental protection have a sensitive agri-environment, which reduces the productive value of the land. Thus, agrienvironmental payments appear not to have the sufficient size nor the type of design that result in inflated land prices.

Accessibility to population presumed to reflect urbanity is shown to be the strongest explanatory factor, regardless of the location of the land. These results are in line with recent findings emphasising the importance of urban sprawl and competition for land from other sectors (Veldkamp and Lambin 2000; Cavailhès and Wavresky 2003). Previous studies conclude that the distance to an urban centre has a large influence on land prices. However, the analytical approach to geographical distances used in most previous studies is relevant only for land located at the urban fringe. This study contributes to previous research in this area by providing empirical estimates based on a spatial index showing the spatial relation of each location to all urban centra across the country.

Considering the complexity of the relations between land prices and locationspecific factors we emphasise the need of more research to better understand the nature of the relations between agricultural and non-agricultural factors on land prices and the various causal effects between pure land productivity factors and other location-specific factors.

Acknowledgements The authors would like to thank Professor Åke E. Andersson and Professor Börje Johansson for valuable comments.

Open Access This article is distributed under the terms of the Creative Commons Attribution License which permits any use, distribution, and reproduction in any medium, provided the original author(s) and the source are credited.

\section{References}

Alston JM (1986) An analysis of growth of US farmland prices. Am J Agr Econ 68:1-9

Anas A, Arnott R, Kenneth AS (1998) Urban spatial structure. J Econ Lit 36(3):1426-1464

Andersson M, Gråsjö U (2009) Spatial dependence and the representation of space in empirical models. Ann Reg Sci 43:159-180

Arnott RJ (1980) A simple urban growth model with durable housing. Reg Sci Urban Econ 10(1):53-76

Arnott JR, Lewis FD (1979) The transition of land to urban use. J Polit Econ 87(1):161-169

Bell KP, Irwin EG (2002) Spatial explicit micro-level modelling of land use change at the rural-urban interface. J Agric Econ 27(3):217-232

Bockstael N (1996) Modeling economics and ecology. The importance of a spatial perspective. Am J Agric Econ 78:1168-1180 
Brady M, Kellerman K, Sahrbacher C, Jelinek L (2009) Impacts of decoupled agricultural support on farm structure, biodiversity and landscape mosaic: some EU results. J Agric Econ 60:563-585

Busby G, Rendle S (2000) The transition from tourism on farms to farm tourism. Tour Manag 21(6):635642

Capozza DR, Helsley RW (1989) The fundamentals of land prices and urban growth. J Urban Econ 26:295-306

Capozza DR, Helsley RW (1990) The stochastic city. J Urban Econ 28:187-203

Capozza DR, Sick GA (1994) The risk structure of land markets. J Urban Econ 35(3):297-319

Cavailhès J, Wavresky P (2003) Urban influences on periurban farmland prices. Eur Rev Agric Econ 30(3):333-357

Clark JS, Fulton M, Scott JT (1993) The inconsistency of land values, land rents, and capitalization formulas. Am J Agric Econ 75(1):147-155

Clonts HA Jr (1970) Influence of urbanization of land values at the urban periphery. Land Econ 46:489497

Dunford RW, Marti CE, Mittelhammer RC (1985) A case study of rural land values at the urban fringe including subjective buyer expectations. Land Econ 61:10-16

Gannon A (1994) Rural tourism as a factor in rural community economic development for economies in transition. J Sustain Tour 2:51-60

Gardner BL (1987) Causes of US farm commodity programs. J Polit Econ 95(2):290-310

Gelan A, Schwarz G (2008) The effect of single farm payments on less favoured areas agriculture in Scotland: a CGE analysis. Agric Food Sci 17:3-17

Gould WW (1992) Quantile regression with bootstrapped standard errors. Stata Tech Bull 9:19-21

Gråsjö U (2006) Knowledge production and spatial spillovers. An accessibility approach. JIBS dissertation series No. 34, Jönköping

Harris CD (1954) The market as a factor in the localization of industry in the united states. Ann Assoc Am Geogr 44(4):315-348

Irwin (2010) New directions for urban economic models of land use change: incorporating spatial dynamics and heterogeneity. J Reg Sci 50:65-91

Irwin EG, Bockstael NE (2004) Land use externalities, open space preservation, and urban sprawl. Reg Sci Urban Econ 34:705-725

Johansson B, Klaesson J, Olsson M (2002) Time distances and labor market integration. Pap Reg Sci 81(3):305-327

Johansson B, Klaesson J, Olsson M (2003) Commuters non-linear response to time distances. J Geogr Syst 5:315-329

Koenker R, Basset G (1978) Regression quantiles. Econometrica 46(1):33-50

Latruffe L, Mouël CL (2009) Capitalization of the government support in agricultural land prices: what do we know. J Econ Surv 23(4):659-691

Mendelsohn R, Nordhaus WD, Shaw D (1994) The impact of global warming on agriculture: a Ricardian analysis. Am Econ Rev 84(4):753-771

Melichar E (1979) Capital gains versus current income in the farming sector. Am J Agric Econ 61:10851092

Miranowski JA, Hammes BD (1984) Implicit prices of soil characteristics for farmland in Iowa. Am J Agric Econ 66(5):746-749

Montgomery DC, Peck EA, Vining GG (2001) Introduction to linear regression analysis, 3rd edn. Wiley, Canada

Oltmer K, Florax R (2001) Impacts of agricultural policy reform on land prices: a quantitative analysis of the literature. Paper prepared for AAEA-CAES annual meeting. American Agricultural Economics Association

Plantinga AJ, Lubowski RN, Stavins RN (2002) The effects of potential land development on agricultural land prices. J Urban Econ 52(3):561-581

Reynolds JE, Timmons JF (1969) Factors affecting farmland values in the United States. Research bulletin, no 566, Agricultural Experiment Station. Iowa State University of Science and Technology

Rude J (2008) Production of the European union's single farm payment. Can J Agric Econ 56(4):457-471

Rutherford TF, Whalley J, Wigle RM (1990) Capitalization, conditionality, and dilution: land prices and the US wheat program. J Policy Model 12(3):605-622

Sckokai P, Moro D (2009) Modelling the impact of the CAP single farm payment on farm investment and output. Eur Rev Agric Econ 36(3):395-423

Shaik S, Helmers GA, Atwood JA (2005) The evolution of farm programs and their contribution to agricultural land values. Am J Agric Econ 87(5):1190-1197 
Sharpley R, Vass A (2006) Tourism, farming and diversification: an attitudinal study. Tour Manag 27:10401052

Shi YJ, Phipps TT, Colyer D (1997) Agricultural land values under urbanizing influences. Land Econ 73(1):90-100

Veall MR, Zimmermann KF (1996) Pseudo- $R^{2}$ measures for some common limited dependent variable models. J Econ Surv 10(3):241-259

Veldkamp A, Lambin EF (2000) Predicting land-use change. Agric Ecosyst Environ 85:1-6

Walford N (2001) Patterns of development in tourism accommodation enterprises on farms in England and Wales. Appl Geogr 21(4):331-345

Weersink A, Clark S, Turvey CG, Sarker R (1999) The effect of agricultural policy on farmland values. Land Econ 75(3):425-439

Weibull JW (1976) An axiomatic approach to the measurement of accessibility. Reg Sci Urban Econ $6(4): 357-379$

Wu JJ (2001) Environmental amenities and the spatial patterns of urban sprawl. Am J Agric Econ 83(3):691-697

Xu R, Mittelhammer RC, Barkley PW (1993) Measuring the contributions of site characteristics to the value of agricultural land. Land Econ 69:356-369 